\title{
Determination of Binding Capacity and Affinity Constants of Sevelamer Hydrochloride and its Market Preparation
}

\author{
Sushanta Biswas ${ }^{1}$, Md. Zakir Sultan ${ }^{2}$, B. K. Sajeeb ${ }^{3}$ and Sitesh C. Bachar ${ }^{4}$ \\ ${ }^{1}$ Department of Pharmaceutical Technology, Faculty of Pharmacy, University of Dhaka, \\ Dhaka-1000, Bangladesh \\ ${ }^{2}$ Drug Analysis and Research Laboratory, Centre for Advanced Research in Sciences (CARS), \\ University of Dhaka, Dhaka-1000, Bangladesh. \\ ${ }^{3}$ Department of Pharmacy, Mawlana Bhashani Science and Technology University, \\ Santosh, Tangail-1902, Bangladesh. \\ ${ }^{4}$ Department of Pharmacy, Faculty of Pharmacy, University of Dhaka, Dhaka-1000, Bangladesh
}

Received: June 17, 2014; Accepted: June 24, 2014; Published (web): June 29, 2014

\begin{abstract}
Sevelamer is an orally administered weakly basic anion exchange resin which consists of crosslinked polymeric amine that binds dietary phosphate in the gastrointestinal tract. This is approved for the treatment of hyperphosphatemia in adult patients with end-stage renal disease. The binding parameter constants of nonabsorbable sevelamer in its hydrochloride form were determined using the Langmuir approximation for its active

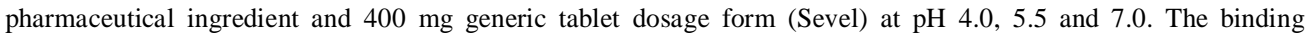
parameters were also compared with the innovator product Renagel $400 \mathrm{mg}$ tablet. The results demonstrate the equivalency of the dosage form at each $\mathrm{pH}$ in terms of the in vitro binding parameters. The results also demonstrate a shift in the binding mechanism from $\mathrm{pH} 4.0$ to 7.0.
\end{abstract}

Key words: Sevelamer hydrochloride; Ion chromatography; Langmuir approximation; affinity constant; Renagel, Sevel.

\section{INTRODUCTION}

Hyperphosphatemia and secondary hyperparathyroidism are common complications of end stage renal disease (ESRD) that, when untreated, may result in increased morbidity and mortality. ${ }^{1}$ Hyperphosphatemia and hypercalcemia have been associated with increased coronary artery calcification. Achieving control of serum phosphorus without increasing serum calcium is an important goal for patients with ESRD. ${ }^{2}$ Although calciumbased phosphate binders effectively reduce serum phosphorus and parathyroid hormone concentrations, these agents can lead to hypercalcemia and have been associated with increased vascular calcification. Aluminum hydroxide is a potent phosphate binder, but concern about skeletal, hematological, and neurological toxicity. ${ }^{3}$

Correspondence to: Sitesh C. Bachar

E-mail: bacharsc63@gmail.com

Dhaka Univ. J. Pharm. Sci. 13(1): 37-49, 2014 (June)
The phosphorus binder, sevelamer ${ }^{4}$ was developed to overcome the limitations associated with the usual management of hyperphosphatemia and secondary hyperparathyroidism (i.e., mineral salts). Sevelamer, a non-absorbable hydrogel, is as efficacious as calcium-based phosphate binders for reducing serum phosphorus but does not cause hypercalcemia or other adverse metabolic effects. Sevelamer also exhibits beneficial effects on lipids, consistently and significantly decreasing LDL cholesterol and increasing HDL cholesterol in most studies. $^{5}$

In patients with chronic kidney disease (CKD) stages $3-5 \mathrm{D}$, there is need to avoid the long-term use of aluminum-containing phosphate binders and in patients with chronic kidney disease (CKD) stage 5D, avoiding dialysate aluminum contamination to prevent aluminum intoxication. Sevelamer hydrochloride is a well-tolerated alternative to calcium- or aluminum-containing phosphate binder in 
the control of serum phosphate in CAPD (continuous ambulatory peritoneal dialysis) patients. Subsequently, the importance of Sevelamer hydrochloride is increasing for hyperphosphatemia.

Renagel tablet (sevelamer $\mathrm{HCl}$ ) administered orally is the brand product of Genzyme Corporation, UK and is being used for the treatment of hyperphosphatemia. Pharmacology, pharmacokinetics study, side effects, contraindications, precautions, efficacy, effectiveness, bioequivalence, clinical study and others study of Renagel tablet were approved by the FDA.

This non-absorbable, non-systemic drug is formulated by ACME Laboratories Ltd. Bangladesh as generic drug with a product name Sevel, containing sevelamer hydrochloride $400 \mathrm{mg}$. The equivalency in terms of efficacy of Sevel tablet (400 $\mathrm{mg}$ ) was taken into consideration to compare with Renagel (400 mg) tablet using in-vitro study. This invitro equivalence study was performed using Langmuir approximation equation approved by FDA.

Utilizing Langmuir equation the binding affinity constant $\left(\mathrm{K}_{1}\right)$ and capacity constant $\left(\mathrm{K}_{2}\right)$ of nonabsorbable sevelamer $\mathrm{HCl}$ and its market preparations (Sevel $400 \mathrm{mg}$ tablet) were determined and compared with innovator drug, Renagel 400mg tablet. Thus the present study was designed to evaluate the in-vitro equivalence of Sevelamer hydrochloride generic preparation available in our markets with the innovator product.

\section{MATERIALS AND METHODS}

Sevelamer hydrochloride powder (API) and Renagel 400 tablet manufactured by Genzyme Corporation, Ireland, UK, containing sevelamer $\mathrm{HCl}$ 400mg were from ACME Laboratories Ltd, The Sevel 400 (B 3001), Sevel 400 (B 3002). Sevel 400 (B 3003) tablet as test products manufactured by ACME Laboratories Ltd, Dhaka, Bangladesh was collected from local market. Potassium monobasic phosphate, N,N-Bis(Hydroxyetyl)-2-aminoethanesulfonic acid (BES), Sodium chloride, Sodium hydroxide, Sodium carbonate, Sodium bicarbonate, Methanol are obtained from Sigma-Aldrich, USA and sulphuric acid was obtained from Merck, Germany. All chemicals were of ACS grade or higher and were used without further purification. Deionized water was obtained from an in-house Barnstead Nanopure System Barnstead/Thermolyne Corporation, Dubuque, IA). Labline heated orbital shaker (Labline 3520 orbital shaker, Hyland scientific, USA) and Ion chromatography (Model no: 881 Compact IC pro 1, Metrohm Ltd., Switzerland), were used in conduction of the study.

\section{Preparation of mobile phase:}

$1 \mathrm{mM} \mathrm{NaHCO}$ and $3.2 \mathrm{mM} \mathrm{Na} \mathrm{CO}_{3}$ solution. In a one liter volumetric flask $80 \mathrm{mg} \mathrm{NaHCO}_{3}$ and $340 \mathrm{mg} \mathrm{Na} \mathrm{CO}_{3}$ were taken and dissolved them with deionized $\mathrm{H}_{2} \mathrm{O}$ made up to one liter. Then the solution was sonicated and filtered through 0.22 micron vacuum filter paper.

Preparation of $\mathbf{H}_{2} \mathrm{SO}_{4}$. In a $1000 \mathrm{ml}$ volumetric flask $5.5 \mathrm{ml}$ conc. $\mathrm{H}_{2} \mathrm{SO}_{4}$ was and diluted with 994.5 $\mathrm{ml}$ deionized $\mathrm{H}_{2} \mathrm{O}$. The solution was sonicated and then filtered through 0.22 micron vacuum filter paper.

Preparation of standard phosphate solution. Three sets of $250 \mathrm{ml}$ volumetric flask were taken. Each set was marked at 8 different phosphate concentration such as $38.7 \mathrm{mM}, 30.0 \mathrm{mM}, 14.5 \mathrm{mM}$, $10.0 \mathrm{mM}, 7.5 \mathrm{mM}, 5.0 \mathrm{mM}, 2.5 \mathrm{mM}, 1.0 \mathrm{mM}$. Required amount of $\mathrm{KH}_{2} \mathrm{PO}_{4}$ was taken appropriately by calculation for 8 different phosphate concentrations. $\mathrm{NaCl} 701.28 \mathrm{mg}(80 \mathrm{mM})$ and $\mathrm{N}, \mathrm{N}-$ Bis(hydroxiethyl)-2-aminoethanesulfonic acid (BES) $3198.75 \mathrm{mg}(100 \mathrm{mM})$ was weighed and added for all the volumetric flasks so that all the solutions contain the same concentration of $\mathrm{BES}$ and $\mathrm{NaCl}$ for maintaining gastrointestinal tract (GIT) chemical environment in-vitro. The final solution was made up to $150 \mathrm{~mL}$ by addition of de-ionized water. Such sets of solutions were prepared for three different $\mathrm{pH}$ (4.0, 5.5 and 7.0) levels adjusted by $1.0 \mathrm{~N}$ hydrochloride acid and $1.0 \mathrm{~N}$ sodium hydroxide. Then all the solutions were placed in Labline Heated Orbital Shaker at $37^{\circ} \mathrm{C}$ temperatures for 2 hours for maintaining GIT in-vitro. The sample flasks were removed from Orbital Shaker and filtered through a 
$25 \mathrm{~mm}, 0.2$ micro meter nylon syringe filter. The solutions were fifty times diluted with deionized water. All the drug-free standard samples were prepared in duplicate for different $\mathrm{pH}$ levels.

Preparation of sample solution. As per above design to $150 \mathrm{ml}$ phosphate solutions, Sevelamer $\mathrm{HCl}$ 400mg (API), Renagel 400mg tablet, Sevel 400 tablet (B 3001), Sevel $400 \mathrm{mg}$ tablet (B 3002) and Sevel $400 \mathrm{mg}$ tablet (B 3003) were added for $\mathrm{pH} 4.0, \mathrm{pH}$ 5.5 and $\mathrm{pH} 7.0$ accordingly. The $\mathrm{pH}$ levels of the solutions were adjusted using $1.0 \mathrm{~N}$ hydrochloride acid and $1.0 \mathrm{~N}$ sodium hydroxide accordingly. All the solutions were placed in Labline Heated Orbital Shaker at $37^{0} \mathrm{C}$ temperatures for 2 hours for maintaining GIT condition in-vitro. The sample flasks were removed from Orbital Shaker and filtered through a $25 \mathrm{~mm}, 0.2$ micro meter nylon syringe filter. The solutions were fifty times diluted with deionized water. All the test samples were prepared in duplicate for different $\mathrm{pH}$ levels. For all solutions the test was performed in triplicates.

Chromatographic conditions. Injector: Auto injector; Column: Polyvinyl alcohol with quaternary ammonium; $150 \times 4.0 \mathrm{~mm}$; Detector: Conductivity detector; Eluent composition: $1 \mathrm{mM}$ sodium bicarbonate and $3.2 \mathrm{mM}$ sodium carbonate; Flow rate: $0.7 \mathrm{ml} / \mathrm{min}$, Injection volume: $20 \mu \mathrm{l}$; Software: Magic Net. An ion chromatogram of standard phosphate solution has been shown in Fig. 1 .

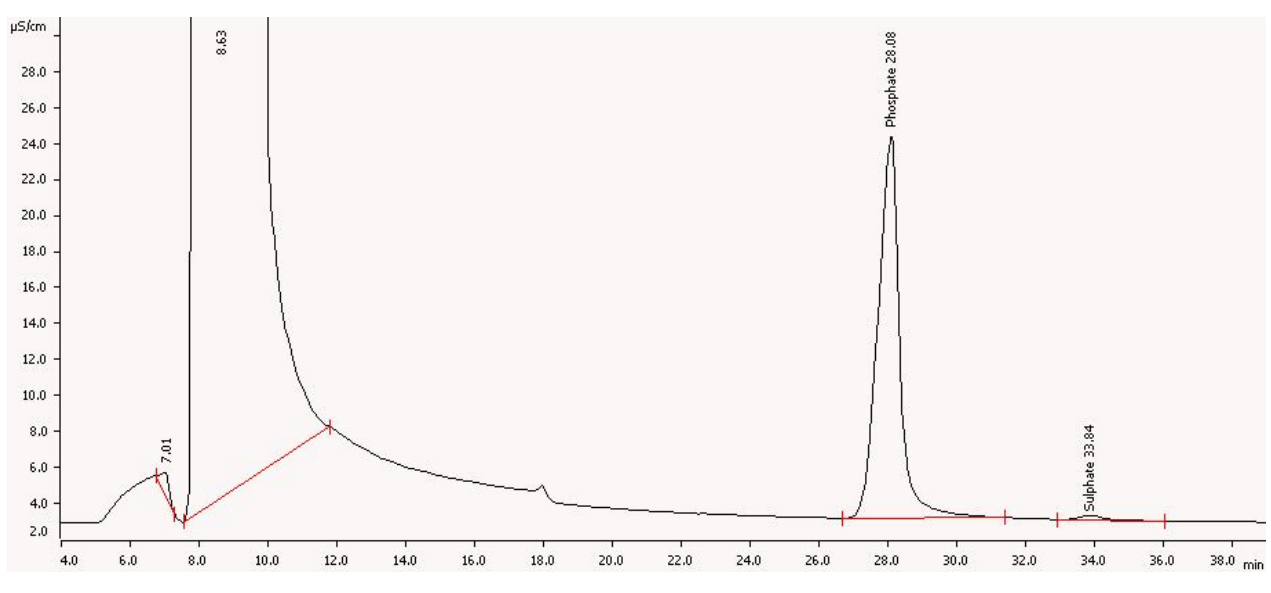

Fig. 1. Ion chromatogram of $2.5 \mathrm{mM}$ standard phosphate

Calculations. The remaining unbound phosphate in terms of concentration in each sample was calculated from the linear regression line obtained from a plot of area of the phosphate peak versus the concentration of the phosphate (mM) using the following equation : ${ }^{6}$

Unbound phosphate concentration $(\mathrm{mM})=\frac{\text { area phosphate }- \text { intercept }}{\text { slope }}$

From the known initial concentration of phosphate in each solution (i.e. 38.7, 30.0, 14.5, 10.0, 7.5, 5.0, 2.5, and $1.0 \mathrm{mM}$ ) before the addition of sevelamer hydrochloride, the bound concentration was calculated by subtracting the unbound concentration from the initial concentration. ${ }^{6}$
Bound phosphate concentration $(\mathrm{mM})=$ initial concentration $(\mathrm{mM})$ - unbound phosphate concentration (mM)

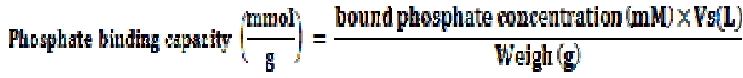

Where, Vs is the volume of the solution, approximately $150 \mathrm{ml}$ or $0.15 \mathrm{~L}$ for the $400 \mathrm{mg}$ tablet and powder. The weigh is the weight of the sevelamer hydrochloride expressed in (g).

The phosphate binding constants were calculated from the Langmuir approximation. The Langmuir approximation describes the monomolecular adsorption of an adsorbate (phosphate) from solution, at constant temperature onto an adsorbent (sevelamer 
hydrochloride). ${ }^{7}$ The process is described by the Langmuir equation:

$$
\frac{C_{o q}}{\frac{x}{m}}=\frac{C_{o q}}{K_{2}}+\frac{1}{K_{1} K_{2}}
$$

Where $\mathrm{Ceq}$ is the concentration of phosphate remaining in $\mathrm{mM}$ in solution at equilibrium or the unbound concentration. The $\mathrm{x} / \mathrm{m}$ is the amount of phosphate bound per weight of polymer in $\mathrm{mM} / \mathrm{g}$. The constant $\mathrm{K}_{1}$ is the affinity constant involved in binding and related to the magnitude of the forces. The constant $\mathrm{K}_{2}$ is the Langmuir capacity constant and is the maximum amount of that can be bound per unit weight of sevelamer hydrochloride. ${ }^{6}$

The affinity constant and Langmuir capacity constants were calculated by performing linear regression on a plot of the unbound phosphate concentration $(\mathrm{mM}) /$ binding capacity $(\mathrm{mM} / \mathrm{g})$ versus unbound phosphate concentration $(\mathrm{mM})$. The $\mathrm{K}_{1}(=\mathrm{a} / \mathrm{b})$ value is calculated by dividing the slope (a) of the regression line by the intercept (b), the $\mathrm{K}_{2}$ $(=1 / \mathrm{a})$ value is equal to the inverse of the slope.

\section{RESULTS}

The present study was designed to evaluate the in vitro equivalencey of sevelamer hydrochloride generic preparation available in our markets with the innovator product. The equivalency in terms of efficacy of Sevel tablet $400 \mathrm{mg}$ of three different batches B 3001, B 3002 and B 3003 of the generic product designated as Sevel B 3001, Sevel B 3002 and Sevel B 3003, was compared with Renagel 400 mg tablet the innovator product using in vitro study. This in vitro equivalence study was performed using Langmuir approximation equation approved by the FDA. ${ }^{6}$ In Langmuir equation the binding affinity constant $\left(\mathrm{K}_{1}\right)$ and capacity constant $\left(\mathrm{K}_{2}\right)$ of Sevelamer $\mathrm{HCl}$ and its market preparations (Sevel 400 tablet) were determined and compared with innovator drug Renagel $400 \mathrm{mg}$ tablet.

Calibration curve of $\mathbf{K H}_{2} \mathbf{P O}_{4}$. Eight different concentration of $\mathrm{KH}_{2} \mathrm{PO}_{4}$ solution were prepared and obtained eight different types of peak areas through ion chromatography. Each solution contains $80 \mathrm{mM}$ $\mathrm{NaCl}$ and $100 \quad \mathrm{mM} \quad$ N,N-Bis(hydroxiethyl)-2aminoethanesulfonic acid (BES) as incubation media for maintaining the chemical environment of GIT invitro. All solutions were kept at Labline orbital shaker for 2.0 hours at $37^{\circ} \mathrm{C}$ for maintaining the physical condition of the GIT. Calibration curves were obtained for $\mathrm{pH} 4.0$ (Fig. 2), pH 5.5 (Fig. 3) and pH 7.0 (Fig. 4). These different $\mathrm{pH}$ levels are observed in different portions in the GIT and were adjusted either by adding $1.0 \mathrm{~N} \mathrm{HCl}$ or $1.0 \mathrm{~N} \mathrm{NaOH}$ in the experimental laboratory. The RSQ values are 0.9999, 0.9998 and 0.9999, slopes 6.801, 7.070 and 7.109 and intercepts were $-0.9542,-1.4086$ and 1.471 for $\mathrm{pH} 4.0, \mathrm{pH} 5.5$ and $\mathrm{pH} 7.0$ respectively (Table 1). These values specially the slopes and intercepts were used in the calculation of unbound phosphate according to Langmuir approximation equation. The bound concentration was calculated by subtracting the unbound concentration from the initial phosphate concentration before the addition of sevelamer $\mathrm{HCl}$ API or its dosage forms.

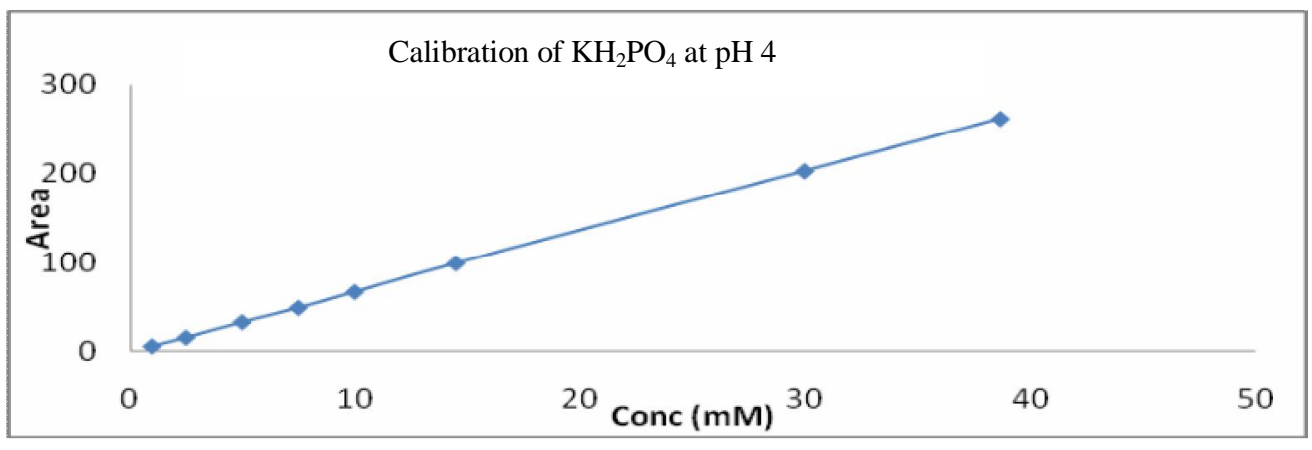

Fig. 2. Calibration curve of $\mathrm{KH}_{2} \mathrm{PO}_{4}$ at $\mathrm{pH} 4.0$ 


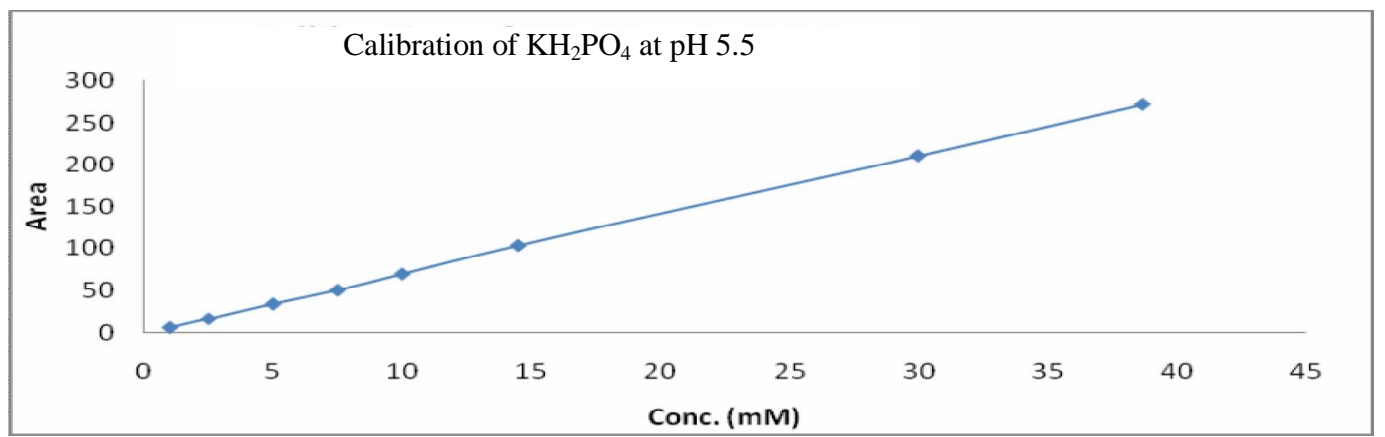

Fig. 3. Calibration curve of $\mathrm{KH}_{2} \mathrm{PO}_{4}$ at $\mathrm{pH} 5.5$

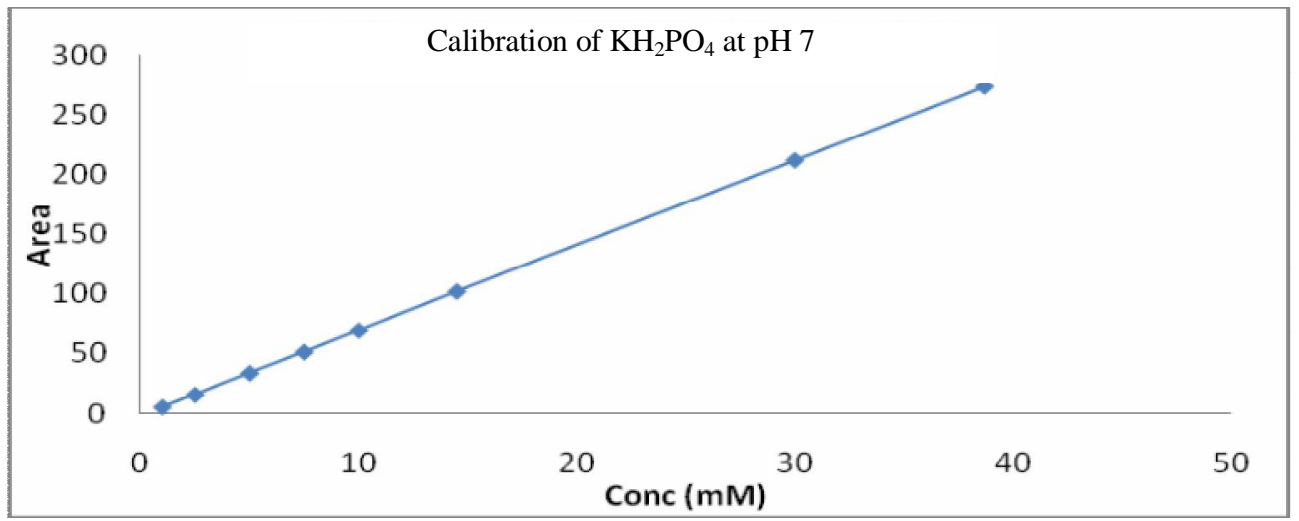

Fig. 4. Calibration curve of $\mathrm{KH}_{2} \mathrm{PO}_{4}$ at $\mathrm{pH}$ 7.0

Table 1. Data of the calibration curve at all $\mathrm{pHs}$

\begin{tabular}{lccc}
\hline & $\mathrm{pH} 4$ & $\mathrm{pH} 5.5$ & $\mathrm{pH} \mathrm{7}$ \\
\hline RSQ & 0.9999 & 0.9998 & 0.99999 \\
Slope & 6.801 & 7.070 & 7.109 \\
Intercept & -0.9542 & -1.4086 & -1.471 \\
\hline
\end{tabular}

Percentage of unbound and bound phosphate at different $\mathbf{p H}$ levels. The unbound phosphate concentration $(\mathrm{mM})$ remaining in each sample was calculated from the linear regression generated plot of area of the phosphate peak against the initial concentration $(\mathrm{mM})$ using intercept and slope of the respective $\mathrm{pH}$ according to Langmuir. ${ }^{6}$ Thus bound phosphate concentration $(\mathrm{mM})$ was also obtained by subtracting unbound phosphate concentration from initial phosphate concentration. At $\mathrm{pH} 4.0$ using the active sevelamer $\mathrm{HCl}$ as binding agent the percentage of bound phosphate were higher in lower initial concentration as compared to the higher initial concentration of phosphate. At lower phosphate concentrations 1.0, 2.5, 5, 7.5, 10 and $14.5 \mathrm{mM}$ the percentage of bound phosphate were 82.5, 70.02, $79.18,78.20,76.34$ and $72.59 \%$, respectively and at higher phosphate concentrations 30 and $38.7 \mathrm{mM}$, the percentage of bound phosphate concentrations were 52.42 and $44.61 \%$, respectively (Table 2 ).

Table 2. Percentage of unbound and bound phosphate of Sevelamer $\mathrm{HCl}$ (API) at pH 4.0

\begin{tabular}{ccc}
\hline $\begin{array}{c}\text { Total phosphate } \\
\text { conc. }(\mathrm{mM})\end{array}$ & \% Unbound $\mathrm{PO}_{4}$ & \% Bound $\mathrm{PO}_{4}$ \\
\hline 1.0 & 17.49 & $82.50 \pm 0.046$ \\
2.5 & 29.97 & $70.02 \pm 0.231$ \\
5.0 & 20.81 & $79.18 \pm 1.131$ \\
7.5 & 21.79 & $78.20 \pm 0.369$ \\
10.0 & 23.65 & $76.34 \pm 0.359$ \\
14.5 & 27.40 & $72.59 \pm 0.227$ \\
30.0 & 47.57 & $52.42 \pm 0.494$ \\
38.7 & 55.38 & $44.61 \pm 0.719$ \\
\hline
\end{tabular}

Similarly at $\mathrm{pH} 4.0$ using the reference product Renagel 400 containing sevelamer $\mathrm{HCl}$ as binding agent the percentage of bound phosphate at lower phosphate concentrations 1.0, 2.5, 5.0, 7.5, 10 and $14.5 \mathrm{mM}$ were $75.15,65.85,60.20,52.60,49.87$ and $47.50 \%$ and at higher phosphate concentrations 30 and $38.7 \mathrm{mM}$, the percentage of bound phosphate concentrations were 36.73 and $35.36 \%$, respectively (Table 3). 
Table 3. Percentage of unbound and bound phosphate of Renagel $400 \mathrm{mg}$ tablets at $\mathrm{pH} 4.0$

\begin{tabular}{ccc}
\hline $\begin{array}{c}\text { Total phosphate } \\
\text { conc. }(\mathrm{mM})\end{array}$ & $\begin{array}{c}\text { \% Unbound } \\
\mathrm{PO}_{4}\end{array}$ & \% Bound $\mathrm{PO}_{4}$ \\
\hline 1.0 & $24.84 \pm$ & $75.15 \pm 1.171$ \\
2.5 & $34.14 \pm$ & $65.85 \pm 2.331$ \\
5.0 & $39.79 \pm$ & $60.20 \pm 1.175$ \\
7.5 & $47.39 \pm$ & $52.60 \pm 1.749$ \\
10.0 & $50.12 \pm$ & $49.87 \pm 0.417$ \\
14.5 & $52.49 \pm$ & $47.50 \pm 0.817$ \\
30.0 & $63.26 \pm$ & $36.73 \pm 0.649$ \\
38.7 & $64.63 \pm$ & $35.36 \pm 0.242$ \\
\hline
\end{tabular}

At pH 4.0 using the test preparation Sevel 400 (B 3001) containing sevelamer $\mathrm{HCl}$ as binding agent the percentage of bound phosphate at lower concentrations $1.0,2.5,5,7.5,10$ and $14.5 \mathrm{mM}$ were $74.15,69.21,63.97,53.85,52.43$ and $48.54 \%$, respectively and at higher phosphate concentrations 30 and $38.7 \mathrm{mM}$, the percentage of bound phosphate concentrations were 38.62 and $36.22 \%$, respectively (Table 4). For the test preparation Sevel 400 (B 3002) the percentage of bound phosphate at concentrations were $75.15,66.25,59.34,52.45,50.31$ and $47.49 \%$ and at higher phosphate concentrations the percentage of bound phosphate concentration were 32.88 and $28.27 \%$, respectively (Table 5 ). For test preparation Sevel 400 (B 3003) the percentage of bound phosphate at lower concentrations were 73.87 , $65.01,60.09,52.06,50.35$ and $47.83 \%$ and at higher phosphate concentrations the percentage of bound phosphate concentration were 36.67 and $33.45 \%$, respectively (Table 6).

Table 4. Percentage of unbound and bound phosphate of Sevel B 3001 tablets at pH 4.0

\begin{tabular}{ccc}
\hline $\begin{array}{c}\text { Total phosphate } \\
\text { conc. }(\mathrm{mM})\end{array}$ & $\begin{array}{c}\text { \% } \\
\text { Unbound } \\
\mathrm{PO}_{4}\end{array}$ & \% Bound $\mathrm{PO}_{4}$ \\
\hline 1.0 & 25.84 & $74.15 \pm 3.089$ \\
2.5 & 30.78 & $69.21 \pm 1.256$ \\
5.0 & 36.02 & $63.97 \pm 0.556$ \\
7.5 & 46.14 & $53.85 \pm 0.419$ \\
10.0 & 47.56 & $52.43 \pm 0.647$ \\
14.5 & 51.45 & $48.54 \pm 1.513$ \\
30.0 & 61.37 & $38.62 \pm 0.582$ \\
38.7 & 63.77 & $36.22 \pm 0.836$ \\
\hline
\end{tabular}

At $\mathrm{pH} 5.5$ using the active sevelamer $\mathrm{HCl}$ as binding agent the percentage of bound phosphate was higher in lower initial concentrations as compared to the higher initial concentrations of phosphate as that of $\mathrm{pH}$ 4.0. At lower phosphate concentrations 1.0, $2.5,5.0,7.5,10$ and $14.5 \mathrm{mM}$ the percentage of bound phosphate were $79.92,89.72,88.92,89.12$, 87.15 and $83.30 \%$, respectively and at higher phosphate concentrations 30 and $38.7 \mathrm{mM}$, the percentage of bound phosphate concentration were 61.33 and $50.11 \%$, respectively (Table 7).

Table 5. Percentage of unbound and bound phosphate of Sevel B 3002 tablets at $\mathrm{pH} 4.0$

\begin{tabular}{ccc}
\hline $\begin{array}{c}\text { Total phosphate } \\
\text { conc. }(\mathrm{mM})\end{array}$ & $\begin{array}{c}\text { \% Unbound } \\
\mathrm{PO}_{4}\end{array}$ & \% Bound $\mathrm{PO}_{4}$ \\
\hline 1.0 & 24.84 & 75.15 \\
2.5 & 33.74 & 66.25 \\
5.0 & 40.65 & 59.34 \\
7.5 & 47.54 & 52.45 \\
10.0 & 49.68 & 50.31 \\
14.5 & 52.50 & 47.49 \\
30.0 & 67.11 & 32.88 \\
38.7 & 71.72 & 28.27 \\
\hline
\end{tabular}

Table 6. Percentage of unbound and bound phosphate of Sevel B 3003 tablets at pH 4.0

\begin{tabular}{ccc}
$\begin{array}{c}\text { Total phosphate } \\
\text { conc. }(\mathrm{mM})\end{array}$ & $\begin{array}{c}\text { Unbound } \\
\mathrm{PO}_{4}\end{array}$ & $\begin{array}{c}\% \text { Bound } \\
\mathrm{PO}_{4}\end{array}$ \\
1.0 & 26.12 & 73.87 \\
2.5 & 34.98 & 65.01 \\
5.0 & 39.99 & 60.09 \\
7.5 & 47.93 & 52.06 \\
10.0 & 49.64 & 50.35 \\
14.5 & 52.16 & 47.83 \\
30.0 & 63.32 & 36.67 \\
38.7 & 66.54 & 33.45 \\
\hline
\end{tabular}

Table 7. Percentage of unbound and bound phosphate of Sevelamer HCl (API) at pH 5.5

\begin{tabular}{ccc}
\hline $\begin{array}{c}\text { Total phosphate } \\
\text { conc. }(\mathrm{mM})\end{array}$ & $\%$ Unbound $\mathrm{PO}_{4}$ & $\%$ Bound $\mathrm{PO}_{4}$ \\
\hline 1.0 & $20.07 \pm$ & $79.92 \pm 0.860$ \\
2.5 & $10.27 \pm$ & $89.72 \pm 0.403$ \\
5.0 & $11.07 \pm$ & $88.92 \pm 0.245$ \\
7.5 & $10.87 \pm$ & $89.12 \pm 0.205$ \\
10.0 & $12.84 \pm$ & $87.15 \pm 0.135$ \\
14.5 & $16.69 \pm$ & $83.30 \pm 0.098$ \\
30.0 & $38.66 \pm$ & $61.33 \pm 0.079$ \\
38.7 & $49.88 \pm$ & $50.11 \pm 1.675$ \\
\hline
\end{tabular}

Similarly at pH 5.5 using the reference product Renagel 400 containing sevelamer $\mathrm{HCl}$ as binding agent the percentage of bound phosphate at lower phosphate concentrations were 80.64, 91.90, 89.95, 
$89.14,87.72$ and $84.65 \%$ and at higher phosphate concentrations the percentage of bound phosphate concentration were 66.62 and 54.92\% (Table 8). For the test preparation Sevel B 3001 containing sevelamer $\mathrm{HCl}$ as binding agent the percentage of bound phosphate at lower phosphate concentrations were $79.65,85.07,80.95,83.27,76.45$ and $72.45 \%$ and at higher phosphate concentrations the percentage of bound phosphate concentration were 56.25 and $46.33 \%$ (Table 9). For the preparation Sevel B 3002 the percentage of bound phosphate at lower phosphate concentrations were 78.96, 85.81, $81.86,83.54,77.67$ and $73.09 \%$ and at higher phosphate concentrations the percentage of bound

Table 8. Percentage of unbound and bound phosphate of Renagel 400 at pH 5.5

\begin{tabular}{ccc}
\hline $\begin{array}{c}\text { Total phosphate } \\
\text { conc. }(\mathrm{mM})\end{array}$ & $\%$ Unbound $\mathrm{PO}_{4}$ & $\%$ Bound $\mathrm{PO}_{4}$ \\
\hline 1.0 & 19.35 & 80.64 \\
2.5 & 8.09 & 91.90 \\
5.0 & 10.04 & 89.95 \\
7.5 & 10.85 & 89.14 \\
10.0 & 12.27 & 87.72 \\
14.5 & 15.34 & 84.65 \\
30.0 & 33.37 & 66.62 \\
38.7 & 45.07 & 54.92 \\
\hline
\end{tabular}

Table 9. Percentage of unbound and bound phosphate of Sevel B 3001 tablets at pH 5.5

\begin{tabular}{ccc}
\hline $\begin{array}{c}\text { Total phosphate } \\
\text { conc. }(\mathrm{mM})\end{array}$ & \% Unbound $\mathrm{PO}_{4}$ & $\%$ Bound $\mathrm{PO}_{4}$ \\
\hline 1.0 & 20.34 & 79.65 \\
2.5 & 14.92 & 85.07 \\
5.0 & 19.04 & 80.95 \\
7.5 & 16.72 & 83.27 \\
10.0 & 23.54 & 76.45 \\
14.5 & 27.54 & 72.45 \\
30.0 & 43.74 & 56.25 \\
38.7 & 53.66 & 46.33 \\
\hline
\end{tabular}

Table 10. Percentage of unbound and bound phosphate of Sevel B 3002 tablets at pH 5.5

\begin{tabular}{ccc}
\hline $\begin{array}{c}\text { Total phosphate } \\
\text { conc. }(\mathrm{mM})\end{array}$ & $\%$ Unbound $\mathrm{PO}_{4}$ & $\%$ Bound $\mathrm{PO}_{4}$ \\
\hline 1.0 & 21.03 & 78.96 \\
2.5 & 14.18 & 85.81 \\
5.0 & 18.13 & 81.86 \\
7.5 & 16.45 & 83.54 \\
10.0 & 22.33 & 77.67 \\
14.5 & 26.90 & 73.09 \\
30.0 & 40.22 & 59.77 \\
38.7 & 51.35 & 48.64 \\
\hline
\end{tabular}

phosphate concentration were 59.77 and $48.64 \%$ (Table 10). Similarly the test product Sevel B 3003 the percentage of bound phosphate at lower phosphate concentrations were $79.75,88.59,83.17$, $85.15,77.97$ and $75.47 \%$ and at higher phosphate concentrations the percentage of bound phosphate concentration were 59.29 and $49.75 \%$ (Table 11).

Table 11. Percentage of unbound and bound phosphate of Sevel B 3003 tablets at pH 5.5

\begin{tabular}{ccc}
\hline $\begin{array}{c}\text { Total phosphate } \\
\text { conc. }(\mathrm{mM})\end{array}$ & \% Unbound $\mathrm{PO}_{4}$ & $\%$ Bound $\mathrm{PO}_{4}$ \\
\hline 1.0 & 20.24 & 79.75 \\
2.5 & 11.40 & 88.59 \\
5.0 & 16.82 & 83.17 \\
7.5 & 14.84 & 85.15 \\
10.0 & 22.02 & 77.97 \\
14.5 & 24.52 & 75.47 \\
30.0 & 40.70 & 59.29 \\
38.7 & 50.24 & 49.75 \\
\hline
\end{tabular}

At $\mathrm{pH} 7$ using the active sevelamer $\mathrm{HCl}$ as binding agent the percentage of bound phosphate were higher in lower initial concentration as compared to the higher initial concentration of phosphate as that of $\mathrm{pH} 4$ and $\mathrm{pH}$ 5.5. At lower phosphate concentrations 1.0, 2.5, 5.0, 7.5, 10 and $14.5 \mathrm{mM}$ the percentage of bound phosphate were $79.29,86.25,84.26,80.13,78.21$ and $63.80 \%$, respectively and at higher phosphate concentrations 30 and $38.7 \mathrm{mM}$, the percentage of bound phosphate concentration were 40.24 and $46.15 \%$, respectively (Table 12). Similarly at $\mathrm{pH} 7$ using the reference product Renagel 400 the percentage of bound phosphate at lower phosphate concentrations were $78.98,90.69,90.99,85.67,84.65$ and $78.37 \%$ and at higher phosphate concentrations the percentage of bound phosphate concentration were 50.10 and $40.29 \%$ (Table 13). For the test product Sevel B 3001 the percentage of bound phosphate at lower phosphate concentrations were 78.46, 91.87, 92.78, $90.22,85.03$ and $78.86 \%$ and at higher phosphate concentrations the percentage of bound phosphate concentration were 56.50 and $46.86 \%$ (Table 14). For the test product Sevel B 3002 the percentage of bound phosphate at lower phosphate concentrations were $78.35,90.65,91.63,87.92,83.57$ and $76.87 \%$ 
and at higher phosphate concentrations the percentage of bound phosphate concentration were 53.14 and $41.76 \%$ (Table 15). For Sevel B 3003 containing sevelamer $\mathrm{HCl}$ as binding agent the percentage of bound phosphate at lower phosphate concentrations were 78.96, 91.99, 92.61, 89.56, 84.95 and $79.16 \%$ and at higher phosphate concentrations the percentage of bound phosphate concentration were 54.99 and $44.29 \%$ (Table 16).

Table 12. Percentage of unbound and bound phosphate of working std. at $\mathbf{p H} 7.0$

\begin{tabular}{|c|c|c|c|c|}
\hline $\begin{array}{l}\text { Total phosphate } \\
\text { conc. }(\mathrm{mM})\end{array}$ & $\%$ & Unbound $\mathrm{PO}_{4}$ & $\%$ & Bound $\mathrm{PO}_{4}$ \\
\hline 1.0 & & 20.70 & & 79.29 \\
\hline 2.5 & & 13.74 & & 86.25 \\
\hline 5.0 & & 15.73 & & 84.26 \\
\hline 7.5 & & 19.86 & & 80.13 \\
\hline 10.0 & & 21.78 & & 78.21 \\
\hline 14.5 & & 36.19 & & 63.80 \\
\hline 30.0 & & 59.75 & & 40.24 \\
\hline 38.7 & & 53.84 & & 46.15 \\
\hline
\end{tabular}

Table 13. Percentage of unbound and bound phosphate of Renagel $400 \mathrm{mg}$ tablets at $\mathrm{pH}$ 7.0

\begin{tabular}{|c|c|c|c|c|}
\hline $\begin{array}{l}\text { Total phosphate } \\
\text { conc. (mM) }\end{array}$ & $\%$ & Unbound $\mathrm{PO}_{4}$ & $\%$ & Bound $\mathrm{PO}_{4}$ \\
\hline 1.0 & & 21.01 & & 78.98 \\
\hline 2.5 & & 9.30 & & 90.69 \\
\hline 5.0 & & 9.00 & & 90.99 \\
\hline 7.5 & & 14.32 & & 85.67 \\
\hline 10.0 & & 15.34 & & 84.65 \\
\hline 14.5 & & 21.62 & & 78.37 \\
\hline 30.0 & & 49.89 & & 50.10 \\
\hline 38.7 & & 59.70 & & 40.29 \\
\hline
\end{tabular}

Table 14. Percentage of bound and unbound phosphate of Sevel B 3001 tablets at pH 7.0

\begin{tabular}{|c|c|c|c|c|}
\hline $\begin{array}{l}\text { Total phosphate } \\
\text { conc. }(\mathrm{mM})\end{array}$ & $\%$ & Unbound $\mathrm{PO}_{4}$ & $\%$ & Bound $\mathrm{PO}_{4}$ \\
\hline 1.0 & & 21.53 & & 78.46 \\
\hline 2.5 & & 8.12 & & 91.87 \\
\hline 5.0 & & 7.21 & & 92.78 \\
\hline 7.5 & & 9.77 & & 90.22 \\
\hline 10.0 & & 14.96 & & 85.03 \\
\hline 14.5 & & 21.13 & & 78.86 \\
\hline 30.0 & & 43.48 & & 56.50 \\
\hline 38.7 & & 53.13 & & 46.86 \\
\hline
\end{tabular}

Langmuir approximation ${ }^{6}$ plot at pH 4.0. At $\mathrm{pH} 4$ using active sevelamer $\mathrm{HCl}$ as binding agent the affinity constant $\left(\mathrm{K}_{1}\right)$ and binding capacity constant
$\left(\mathrm{K}_{2}\right)$ values were determined by plotting unbound phosphate concentration $(\mathrm{mM}) /$ binding capacity $(\mathrm{mM} / \mathrm{gm})$ versus unbound phosphate concentration $(\mathrm{mM})$ at this $\mathrm{pH}$ (Table 17). The RSQ value, slope and intercept of the regressed plot were determined and the $K_{1}$ and $K_{2}$ values were obtained from these values respectively for samples, respectively.

Table 15. Percentage of bound and unbound phosphate of Sevel B 3002 tablets at pH 7.0

\begin{tabular}{ccc}
\hline $\begin{array}{c}\text { Total phosphate } \\
\text { conc. }(\mathrm{mM})\end{array}$ & \% Unbound $\mathrm{PO}_{4}$ & \% Bound $\mathrm{PO}_{4}$ \\
\hline 1.0 & 21.64 & 78.35 \\
2.5 & 9.34 & 90.65 \\
5.0 & 8.36 & 91.63 \\
7.5 & 12.07 & 87.92 \\
10.0 & 16.42 & 83.57 \\
14.5 & 23.12 & 76.87 \\
30.0 & 46.85 & 53.14 \\
38.7 & 58.23 & 41.76 \\
\hline
\end{tabular}

Table 16. Percentage of bound and unbound phosphate of Sevel $400($ B 3003) at $\mathrm{pH} 7$

\begin{tabular}{ccc}
\hline $\begin{array}{c}\text { Total phosphate } \\
\text { conc. }(\mathrm{mM})\end{array}$ & $\%$ Unbound $\mathrm{PO}_{4}$ & $\%$ Bound $\mathrm{PO}_{4}$ \\
\hline 1.0 & 21.03 & 78.96 \\
2.5 & 8.00 & 91.99 \\
5.0 & 7.38 & 92.61 \\
7.5 & 10.43 & 89.56 \\
10.0 & 15.04 & 84.95 \\
14.5 & 20.83 & 79.16 \\
30.0 & 45.01 & 54.99 \\
38.7 & 55.70 & 44.29 \\
\hline
\end{tabular}

The combined Langmuir plot of unbound phosphate verses unbound phosphate/binding capacity (Table 17) at pH 4 of Sevelamer $\mathrm{HCl}$ (API), Renagel $400 \mathrm{mg}$ tablet, Sevel $400 \mathrm{mg}$ tablet (B 3001), Sevel $400 \mathrm{mg}$ tablet (B 3002) and Sevel $400 \mathrm{mg}$ tablet B 3003 were shown in Fig. 5. The Langmuir affinity constant $\left(\mathrm{K}_{1}\right)$, binding capacity constant $\left(\mathrm{K}_{2}\right)$, RSQ, slope and intercept were very similar for all samples at this $\mathrm{pH}$ as shown in Table 18.

At $\mathrm{pH} 5.5$ using active sevelamer $\mathrm{HCl}$ as binding agent the affinity constant $\left(\mathrm{K}_{1}\right)$ and binding capacity constant $\left(\mathrm{K}_{2}\right)$ values were also determined by plotting unbound phosphate concentration $(\mathrm{mM}) /$ binding capacity $(\mathrm{mM} / \mathrm{gm})$ versus unbound phosphate concentration (mM) at this pH (Table 19). The RSQ 
value, slope and intercept of the regressed plot were determined and the $K_{1}$ and $K_{2}$ values were obtained from these values respectively for samples respectively.

The combined Langmuir plot of unbound phosphate verses unbound phosphate/binding capacity (Table 19) at $\mathrm{pH} 5.5$ of Sevelamer $\mathrm{HCl}$ (API), Renagel 400 mg tablet, Sevel B 3001400 mg tablet, Sevel B $3002400 \mathrm{mg}$ tablet and Sevel B 3003 $400 \mathrm{mg}$ tablet were shown in Fig. 6. The Langmuir affinity constant $\left(\mathrm{K}_{1}\right)$, binding capacity constant $\left(\mathrm{K}_{2}\right)$, RSQ, slope and intercept were very similar for all samples at this $\mathrm{pH}$ as shown in Table 20.

At $\mathrm{pH} 7.0$ using active sevelamer $\mathrm{HCl}$ as binding agent the affinity constant $\left(\mathrm{K}_{1}\right)$ and binding capacity constant $\left(\mathrm{K}_{2}\right)$ values were also determined by plotting unbound phosphate concentration $(\mathrm{mM}) /$ binding capacity $(\mathrm{mM} / \mathrm{gm})$ versus unbound phosphate concentration $(\mathrm{mM})$ at this $\mathrm{pH}$ (Table 21). The RSQ value, slope and intercept of the regressed plot were determined and the $\mathrm{K}_{1}$ and $\mathrm{K}_{2}$ values were obtained from these values respectively for samples respectively.

The combined Langmuir plot of unbound phosphate verses unbound phosphate/binding capacity (Table 19) at $\mathrm{pH} 7.0$ of Sevelamer $\mathrm{HCl}$ (API), Renagel $400 \mathrm{mg}$ tablet, Sevel $400 \mathrm{mg}$ tablet (B 3001), Sevel $400 \mathrm{mg}$ tablet (B 3002) and Sevel 400 $\mathrm{mg}$ tablet B 3003 were shown in Fig. 7. The Langmuir affinity constant $\left(\mathrm{K}_{1}\right)$, binding capacity constant $\left(\mathrm{K}_{2}\right)$, RSQ, slope and intercept were very similar for all samples at this $\mathrm{pH}$ as shown in Table 22.

At each individual $\mathrm{pH}$, sevelamer hydrochloride powder (working std.), Sevel $400 \mathrm{mg}$ (B 3001), Sevel $400 \mathrm{mg}$ (B 3002), Sevel $400 \mathrm{mg}$ (B 3003) tablet, Renagel 400 mg tablet exhibited very similar binding properties. The affinity constant $\left(\mathrm{K}_{1}\right)$ of all samples increased gradually form $\mathrm{pH} 4.0$ to 7.0 .

Table 17. Unbound phosphate concentration and unbound $\mathrm{PO}_{4} /$ binding capacity of test and reference products at $\mathrm{pH} 4.0$

\begin{tabular}{cccccccccc}
\hline \multicolumn{2}{c}{ Sevelamer (API) } & \multicolumn{2}{c}{ Renagel 400 } & \multicolumn{2}{c}{ Sevel 400 (B 3001) } & \multicolumn{2}{c}{ Sevel 400 (B 3002) } & \multicolumn{2}{c}{ Sevel 400 (B 3003) } \\
\hline $\begin{array}{c}\text { Unbound } \\
\text { PO4 Conc. } \\
\text { mM }\end{array}$ & $\begin{array}{c}\text { Unbound/B } \\
\text { capacity }\end{array}$ & $\begin{array}{c}\text { Unbound } \\
\text { PO4 Conc. } \\
\mathrm{mM}\end{array}$ & $\begin{array}{c}\text { Unbound/B } \\
\text { capacity }\end{array}$ & $\begin{array}{c}\text { Unbound } \\
\text { PO4 Conc. } \\
\mathrm{mM}\end{array}$ & $\begin{array}{c}\text { Unbound/B } \\
\text { capacity }\end{array}$ & $\begin{array}{c}\text { Unbound PO4 } \\
\text { Conc. mM }\end{array}$ & $\begin{array}{c}\text { Unbound/ } \\
\text { B capacity }\end{array}$ & $\begin{array}{c}\text { Unbound PO4 } \\
\text { Conc. mM }\end{array}$ & $\begin{array}{c}\text { Unbound/B } \\
\text { capacity }\end{array}$ \\
\hline 0.174 & 0.565 & 0.248 & 0.881 & 0.258 & 0.929 & 0.248 & 0.881 & 0.261 & 0.943 \\
0.749 & 1.141 & 0.853 & 1.382 & 0.769 & 1.185 & 0.843 & 1.358 & 0.874 & 1.434 \\
1.040 & 0.700 & 1.989 & 1.762 & 1.801 & 1.501 & 2.032 & 1.826 & 1.999 & 1.777 \\
1.634 & 0.742 & 3.554 & 2.402 & 3.460 & 2.284 & 3.565 & 2.416 & 3.595 & 2.455 \\
2.365 & 0.826 & 5.012 & 2.679 & 4.756 & 2.418 & 4.968 & 2.633 & 4.964 & 2.629 \\
3.973 & 1.006 & 7.611 & 2.946 & 7.460 & 2.826 & 7.613 & 2.948 & 7.564 & 2.908 \\
14.273 & 2.420 & 18.978 & 4.591 & 18.413 & 4.237 & 20.135 & 5.443 & 18.997 & 4.604 \\
21.434 & 3.310 & 25.014 & 4.874 & 24.681 & 4.695 & 27.758 & 6.765 & 25.754 & 5.305 \\
\hline
\end{tabular}

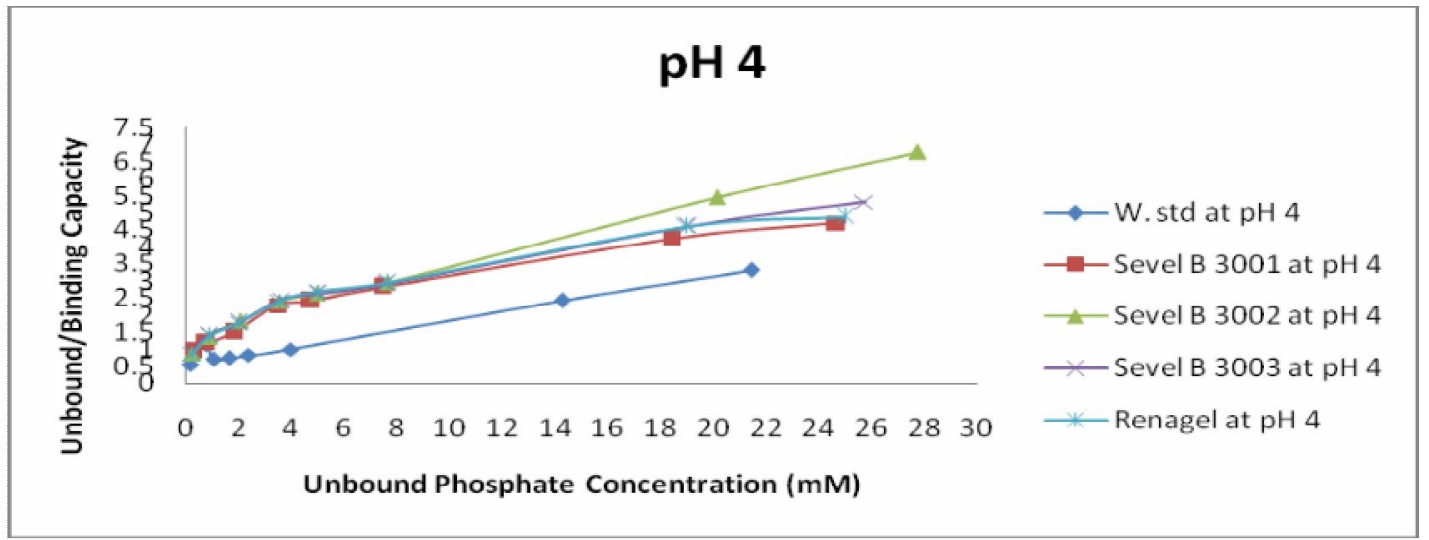

Fig. 5. Langmuir plot of working standard (Sevelamer HCl), Renagel 400 mg, Sevel 400 (B 3001), Sevel 400 (B 3002 ) and Sevel 400 (B 3003) at $\mathrm{pH} 4.0$ 
Table 18. The Langmuir capacity and affinity constants of reference and test products calculated at pH 4.0

\begin{tabular}{lccccc}
\hline & $\begin{array}{c}\text { Sevelamer } \\
(\mathrm{API})\end{array}$ & Renagel 400 & $\begin{array}{c}\text { Sevel 400 } \\
(\mathrm{B} 3001)\end{array}$ & $\begin{array}{c}\text { Sevel 400 } \\
(\mathrm{B} 3002)\end{array}$ & $\begin{array}{c}\text { Sevel 400 } \\
(\mathrm{B} 3003)\end{array}$ \\
\hline RSQ & 0.9680 & 0.9230 & 0.9348 & 0.9816 & 0.9504 \\
Slope & 0.1242 & 0.1504 & 0.1472 & 0.2005 & 0.1578 \\
Intercept & 0.6305 & 1.5002 & 1.3760 & 1.3507 & 1.4941 \\
$k_{2}$ & 8.0503 & 6.6457 & 6.7907 & 4.9874 & 6.3350 \\
$k_{1}$ & 0.1969 & 0.1002 & 0.1070 & 0.1484 & 0.1054 \\
\hline
\end{tabular}

Table 19. Unbound phosphate concentration and unbound $\mathrm{PO}_{4} /$ binding capacity of test and reference products at pH 5.5.

\begin{tabular}{|c|c|c|c|c|c|c|c|c|c|}
\hline \multicolumn{2}{|c|}{ Sevelamer API } & \multicolumn{2}{|c|}{ Renagel 400mg } & \multicolumn{2}{|c|}{ Sevel B 3001 400mg } & \multicolumn{2}{|c|}{ Sevel B 3002 400mg } & \multicolumn{2}{|c|}{ Sevel B 3003 400mg } \\
\hline $\begin{array}{l}\text { Unbound } \\
\text { PO4 } \\
\text { Conc.mM }\end{array}$ & $\begin{array}{l}\text { Unbound/B } \\
\text { capacity }\end{array}$ & $\begin{array}{c}\text { Unbound } \\
\text { PO4 } \\
\text { Conc.mM }\end{array}$ & $\begin{array}{l}\text { Unbound/B } \\
\text { capacity }\end{array}$ & $\begin{array}{c}\text { Unbound } \\
\text { PO4 } \\
\text { Conc.mM }\end{array}$ & $\begin{array}{l}\text { Unbound/B } \\
\text { capacity }\end{array}$ & $\begin{array}{c}\text { Unbound } \\
\text { PO4 } \\
\text { Conc.mM }\end{array}$ & $\begin{array}{c}\text { Unbound/B } \\
\text { capacity }\end{array}$ & $\begin{array}{l}\text { Unbound } \\
\text { PO4 } \\
\text { Conc.mM }\end{array}$ & $\begin{array}{c}\text { Unbound/B } \\
\text { capacity }\end{array}$ \\
\hline 0.200 & 0.668 & 0.193 & 0.640 & 0.203 & 0.681 & 0.210 & 0.710 & 0.202 & 0.676 \\
\hline 0.256 & 0.305 & 0.202 & 0.234 & 0.373 & 0.467 & 0.354 & 0.440 & 0.285 & 0.343 \\
\hline 0.553 & 0.332 & 0.502 & 0.297 & 0.952 & 0.627 & 0.906 & 0.590 & 0.841 & 0.539 \\
\hline 0.815 & 0.325 & 0.813 & 0.324 & 1.254 & 0.535 & 1.234 & 0.525 & 1.113 & 0.464 \\
\hline 1.284 & 0.393 & 1.228 & 0.373 & 2.354 & 0.821 & 2.234 & 0.766 & 2.202 & 0.753 \\
\hline 2.420 & 0.534 & 2.225 & 0.483 & 3.993 & 1.013 & 3.901 & 0.981 & 3.556 & 0.866 \\
\hline 11.598 & 1.680 & 10.012 & 1.335 & 13.123 & 2.073 & 12.067 & 1.794 & 12.215 & 1.830 \\
\hline 19.305 & 2.654 & 17.443 & 2.188 & 20.769 & 3.088 & 19.875 & 2.815 & 19.445 & 2.693 \\
\hline
\end{tabular}

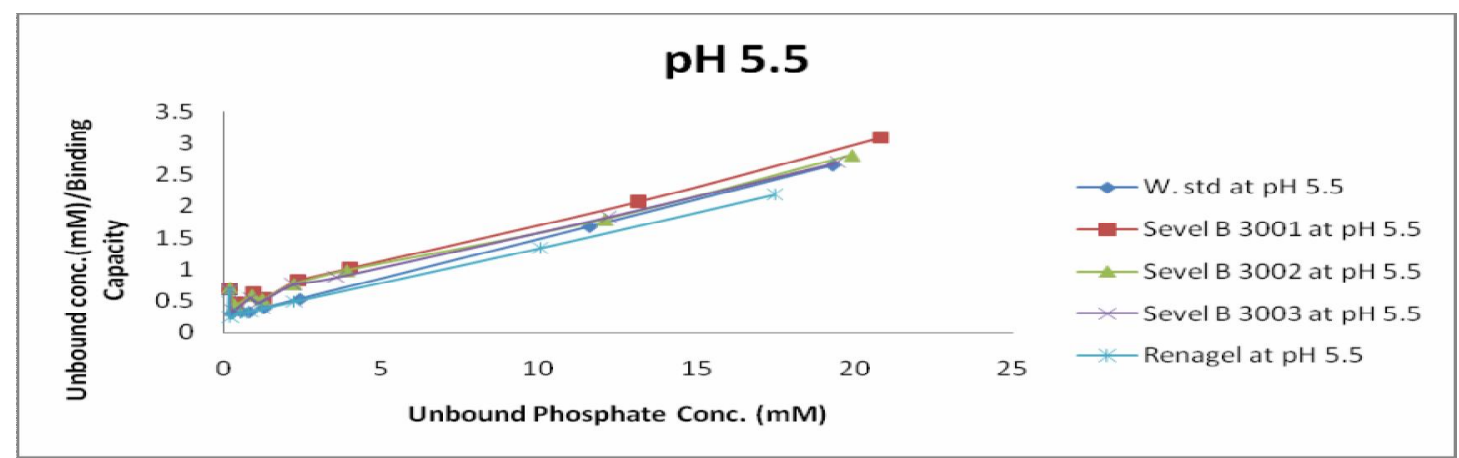

Fig. 6. Langmuir plot of working standard (Sevelamer HCl), Renagel 400 mg, Sevel 400 (B 3001), Sevel 400 (B 3002), and Sevel 400 (B 3003) at $\mathrm{pH} 5.5$

Table 20. The Langmuir capacity and affinity constants calculated at pH 5.5

\begin{tabular}{cccccc}
\hline & Sevelamer API & Renagel 400 & $\begin{array}{c}\text { Sevel 400 } \\
\text { (B 3001) }\end{array}$ & $\begin{array}{c}\text { Sevel 400 } \\
\text { (B 3002 })\end{array}$ & $\begin{array}{c}\text { Sevel 400 } \\
(\text { B 3003) }\end{array}$ \\
\hline RSQ & 0.974 & 0.962 & 0.991 & 0.985 & 0.983 \\
Slope & 0.119 & 0.106 & 0.123 & 0.114 & 0.114 \\
Intercept & 0.317 & 0.300 & 0.500 & 0.494 & 0.449 \\
$k_{2}$ & 8.371 & 9.393 & 8.111 & 8.739 & 8.711 \\
$k_{1}$ & 0.375 & 0.354 & 0.246 & 0.232 & 0.255 \\
\hline
\end{tabular}


Table 21. Unbound phosphate concentration and unbound $\mathrm{PO}_{4} /$ binding capacity of test and reference products at $\mathrm{pH}$ 7.0

\begin{tabular}{cccccccccc}
\hline \multicolumn{2}{c}{ Sevelamer API } & \multicolumn{2}{c}{ Renagel 400mg } & \multicolumn{2}{c}{ Sevel 3001 400mg } & \multicolumn{2}{c}{ Sevel 3002 400mg } & \multicolumn{2}{c}{ Sevel 3003 400mg } \\
\hline $\begin{array}{c}\text { Unbound } \\
\text { PO4 }\end{array}$ & $\begin{array}{c}\text { Unbound/B } \\
\text { capacity }\end{array}$ & $\begin{array}{c}\text { Unbound } \\
\text { PO4 } \\
\text { Conc.mM }\end{array}$ & $\begin{array}{c}\text { Unbound/B } \\
\text { capacity }\end{array}$ & $\begin{array}{c}\text { Unbound } \\
\text { PO4 } \\
\text { Conc.mM }\end{array}$ & $\begin{array}{c}\text { Unbound/B } \\
\text { capacity }\end{array}$ & $\begin{array}{c}\text { Unbound } \\
\text { PO4 } \\
\text { Conc.mM }\end{array}$ & $\begin{array}{c}\text { Unbound/B } \\
\text { capacity }\end{array}$ & $\begin{array}{c}\text { Unbound } \\
\text { PO4 } \\
\text { Conc.mM }\end{array}$ & $\begin{array}{c}\text { Unbound/B } \\
\text { capacity }\end{array}$ \\
\hline 0.207 & 0.696 & 0.210 & 0.709 & 0.215 & 0.731 & 0.216 & 0.736 & 0.210 & 0.710 \\
0.343 & 0.424 & 0.232 & 0.273 & 0.203 & 0.235 & 0.233 & 0.274 & 0.201 & 0.232 \\
0.786 & 0.498 & 0.450 & 0.263 & 0.360 & 0.207 & 0.418 & 0.243 & 0.369 & 0.212 \\
1.490 & 0.661 & 1.074 & 0.446 & 0.732 & 0.288 & 0.905 & 0.366 & 0.782 & 0.310 \\
2.178 & 0.742 & 1.534 & 0.483 & 1.496 & 0.469 & 1.642 & 0.524 & 1.504 & 0.472 \\
5.247 & 1.512 & 3.135 & 0.735 & 3.064 & 0.714 & 3.352 & 0.801 & 3.020 & 0.701 \\
17.925 & 3.959 & 14.967 & 2.655 & 13.046 & 2.0521 & 14.055 & 2.350 & 13.501 & 2.181 \\
20.837 & 3.110 & 23.105 & 3.950 & 20.564 & 3.023 & 22.535 & 3.717 & 21.556 & 3.353 \\
\hline
\end{tabular}

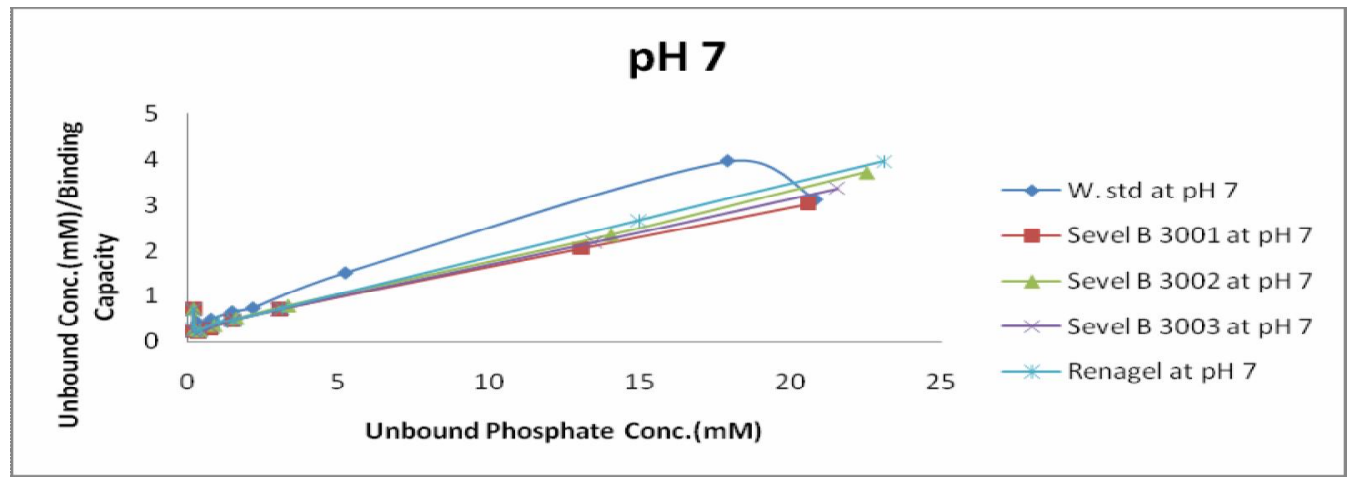

Fig. 7. Langmuir plot of working standard (Sevelamer HCl), Renagel 400 mg, Sevel B 3001, Sevel B 3002, and Sevel B 3003 at pH 7

Table 22. The Langmuir capacity and affinity constants of all sample calculated at pH 7.0

\begin{tabular}{cccccc}
\hline & Sevelamer API & Renagel 400mg & Sevel B 3001 & Sevel B 3002 & Sevel B 3003 \\
\hline RSQ & 0.924 & 0.987 & 0.9722 & 0.9827 & 0.9794 \\
Slope & 0.154 & 0.156 & 0.1322 & 0.1486 & 0.1408 \\
Intercept & 0.502 & 0.314 & 0.3096 & 0.3212 & 0.2973 \\
$\mathrm{k}_{2}$ & 6.462 & 6.385 & 7.5635 & 6.7269 & 7.0992 \\
$\mathrm{k}_{1}$ & 0.307 & 0.497 & 0.4270 & 0.4627 & 0.4736 \\
\hline
\end{tabular}

\section{DISCUSSION}

The in vitro equivalence study of Sevel $400 \mathrm{mg}$ tablet was compared with reference brand product Renagel $400 \mathrm{mg}$ tablet by maintaining GIT condition by the help of Langmuir approximation approved by FDA. ${ }^{6}$ This study was performed to evaluate the efficacy of the generic drug Sevel $400 \mathrm{mg}$ tablet with the innovator product Renagel $400 \mathrm{mg}$ tablet.

The non-linearity of the Langmuir plot and the order of magnitude decrease in the affinity constants $\left(\mathrm{K}_{1}\right)$ at $\mathrm{pH} 4.0$ can be explained by examining the fraction of each phosphate ion present as a function of $\mathrm{pH}$ in dilute solution. This is accomplished by taking into account the hydronium ion concentration at each $\mathrm{pH}$, the $\mathrm{pKa}$ of each phosphate ion and the equilibrium reaction. ${ }^{6}$ At $\mathrm{pH}$ range of approximately 6 - 8, monobasic phosphate is in equilibrium with dibasic phosphate. It has been demonstrated that dibasic phosphate is predominately bound species at $\mathrm{pH} 7.0^{8}$

At $\mathrm{pH}$ 5.5-6.0, the fraction of the monobasic ion increases. The small decreases in the binding affinity constant $\left(\mathrm{K}_{1}\right)$ demonstrates that the the binding force are weaker at $\mathrm{pH} 5.5-6.0$. This is due to the decrease in the amount of dibasic phosphate bound and increase in the amount of the monobasic bound. At 
$\mathrm{pH} 4.0$, the monobasic phosphate ion is predominately present. The affinity constants $\left(\mathrm{K}_{1}\right)$ are an order of magnitude lower at $\mathrm{pH} 4.0$ than the affinity constants $\left(\mathrm{K}_{1}\right)$ at $\mathrm{pH}$ 7.0. These results suggest that the monobasic ion, which has only one site for binding, is more weakly bound than the dibasic ion, which has two sites for binding. ${ }^{6}$

The linearity of the Langmuir plots indicates mono-molecular binding. The relative non-linearity of the Langmuir plots at $\mathrm{pH} 4.0$ may indicate nonmonomolecular binding as a result of monobasic ion. The dibasic binding of phosphate at $\mathrm{pH} 7.0$ and 5.5 of the test and reference were observed where the monobasic binding of phosphate was observed only at $\mathrm{pH}$ 4.0. The lower slope of the curve at $\mathrm{pH} 4.0$ also demonstrates the lower binding affinity of monobasic ion.

A possible explanation for the similarities of the Langmuir plot at $\mathrm{pH} 7.0$ and 5.5 is the apparent $\mathrm{pKa}$ values. The fraction of each ion at various $\mathrm{pH}$ in dilute solution with only phosphoric acid present in water. Sevelamer hydrochloride has an internal charge and hence its own internal ionic strength due to the amines, which are present. This intermolecular charge of sevelamer hydrochloride may shift the $\mathrm{pKa}$ of the dibasic anion from 7.2 to a slightly lower value when in solution and in contact with sevelamer hydrochloride. This would cause the fraction of the dibasic ion, at $\mathrm{pH} 5.5$, to be substantially more than predicted. ${ }^{6}$

It shows a preference for phosphate over other intestinal anions, such as chloride and bicarbonate. The preference for phosphate is believed to be due to its dianion character, and may also involve hydrogen bonding. The absorption of phosphate in vitro is rapid (less than a minute) relative to the time of passage of such a drug through the small intestine (hours). It has also been found to prevent the absorption of dietary phosphate in vivo and in humans. ${ }^{8}$

\section{CONCLUSION}

Sevelamer hydrochloride (polyallylamine crosslinked with epichlorohydrin) is a polymeric hydrogel that has been developed as an oral pharmaceutical to prevent the absorption of dietary phosphate by kidney dialysis patients. It has been found to bind to phosphate in vitro, and to do so more effectively than a wide range of other cationic polymers. The results demonstrates that at each individual $\mathrm{pH}$, Sevelamer hydrochloride (API), different batches of Sevel $400 \mathrm{mg}$ tablets and Renagel 400 mg tablet exhibited very similar binding properties showing equivalent kinetic properties in vitro. So, it is evident that a good efficacy of generic drug Sevel $400 \mathrm{mg}$ tablets manufactured by ACME Laboratories Ltd, Dhaka, Bangladesh was observed in terms of its Langmuir binding capacity constants $\left(\mathrm{K}_{2}\right)$ and affinity constants $\left(\mathrm{K}_{1}\right)$ as compared to innovator drug Renagel $400 \mathrm{mg}$ tablets. So, Renagel $400 \mathrm{mg}$ tablet manufactured by Genzyme Corporation, Ireland, UK can be substituted by generic product Sevel $400 \mathrm{mg}$ tablet manufactured by ACME Laboratories Ltd, Dhaka, Bangladesh.

\section{ACKNOWLEDGEMENTS}

The authors are indebted to the authority of ACME Laboratories limited for giving permission in conduction of this research work. We are also grateful to the Centre for Advance Research in Sciences (CARS), University of Dhaka for physical support and analysis of the samples.

\section{REFERENCES}

1. Block, G.A., Hulbert-Sheraton, T.E. and Levin, N.W. 1998. Association of serum phosphorus and calcium $x$ phosphate product with mortality risk in chronic hemodialysis patients: a national study. Am. J. Kidney Disease 31, 607-617.

2. Kestenbaum, B., Sampson, J.N. and Rudser, K.D. 2005. Serum phosphate levels and mortality risk among people with chronic kidney disease. J. Am. Soc. Nephrol. 16, 520-528.

3. Chertow, G.M. 2003. Slowing the progression of vascular calcification in hemodialysis. J Am Soc Nephrol. 14, 310-314.

4. Rosenbaum, D.P., Mandeville, W.H., Pitruzzello, M. and Goldberg, D.I. 1997. Nephrology Dialysis Transplantation Effect of RenaGel A, a Non-Absorbable , Cross-Linked, Polymeric Phosphate Binder, on Urinary Phosphorus Excretion in Rats. Nephrol. Dial. Transplant 12, 961-964.

5. Nolan, C.R. and Qunibi, W.Y. 2005. Treatment of hyperphosphatemia in patients with chronic kidney disease on maintenance hemodialysis. Kidney Int. Suppl. 95, S13-S20. 
6. Ronald, A.S., Xi, C., John, S.P., Kristine, S.R., Donghui, W. and Eugene, Z. 2002. Determination of the binding parameter constants of Renagel ${ }^{\circledR}$ capsules and tablets utilizing the Langmuir approximation at various $\mathrm{pH}$ by ion chromatography. J. Pharm. Biomed. Anal. 29, 195-201.

7. Johns, W. and Bates, T. 1969. Quantification of binding tendencies of cholestyramine I: Effects of structure and added electrolytes on the binding of unconjugated and conjugated bile salt anions. J. Pharm. Sci. 58, 179-183.
8. Farley, R-H. S., Mandeville, W.H, Ward, J. and Miller, K.L. 2007. Design and development of sevelamer hydrochloride: A novel phosphate binding pharmaceutical. J. Macro. Sci., Part A: Pure Appl. Chem. 36, 1085-1091. 